\title{
Multifunctionality of the Pragmatic Marker 'Pamaanah' in Yemeni Spoken Arabic
}

\author{
Dr. Hameed Yahya A. Al-Zubeiry \\ Associate Professor of Applied Linguistics \\ Department of English - Faculty of Science \& Arts - Baljurashi \\ (Al-Baha University) \\ halzubeiry@bu.edu.sa/hameedyahya@gmail.com
}

\begin{abstract}
PM 'Pamaanah' in the corpus of Yemeni spoken Arabic. A total of 174 audio-recorded data of natural conversations were analyzed as spoken corpus of Yemeni Arabic. The study is based on an eclectic analytical method whose views have been drawn from the theoretical frameworks of the speech act theory, politeness theory, model of functional systemic linguistics (the interpersonal metafunction), and relevance theory. The findings of the study show that the PM 'Pamaanah' functions as: an expression of oath; a commitment marker to a future action on the part of the speaker and the addressee; a mitigation marker, preceding potentially face-threating speech acts; a signal introducing reprimanding; an attitude marker expressing a speaker's attitude and emotion; an epistemic marker evaluating the subjectivity of the speaker's propositional content; an entreaty-marker on directive act; and a displeasure marker on the part of the speaker. The study concluded with a suggestion on conducting a further research exploring the discourse functions of the marker.
\end{abstract}

Keywords: multifunctionality, pragmatic marker, Yemeni spoken Arabic, Pamaanah.

\section{Introduction}

It goes without saying that language functions as a means of communication among individuals. Language can be used to convey information or describe the world. A speaker, for instance, can encode utterances that communicate his thoughts, feelings, and attitudes and describe places, events, and things round him. It is also through the same language a speaker can produce utterances that express his purposes in different situational and social contexts, such as: arguing, blaming, reprimanding, requesting, inviting, apologizing, complaining, to mention just a few. In order to fulfil his goals of communication, the speaker uses linguistic elements in his utterances that provide an indication to the intended meaning of the propositional content and force of the produced utterances. The use of such linguistic elements and their functions in certain contexts is the major concern of discourse analysis and pragmatic fields of language study. According to Brown and Yule (1983, p. 27), discourse analysis and pragmatics are concerned with the analysis of language in use; both focus on the description of linguistic elements, their purposes and functions in a piece of spoken discourse. 
In an interactional communication, speakers usually use linguistic elements in their utterances that have functions other than the ones used to encode propositional content or force. In fact, such non-propositional elements of utterance meaning (content or force) are analyzed as different types of signals; they are referred to as pragmatic markers (Fraser, 1996). The functions and characteristics of pragmatic markers (henceforth PMs) have attracted the interests of a large number of researchers who considered them across languages, to name a few: Östman, (1981), Schiffrin, (1987), Fraser (1996), Schourup (1999), and Blackmore, (2002) in English; Aijmer and Simon-Vandenbergen, (2003) in Swedish; Maschler, (1998), Ziv, (1998), and Shloush, (1998) in Hebrew; Tsai \& Chu, (2017) in Chinese; Al-Batal, (1994), and Alkhalil, (2005) in Arabic; and Vaskó, (2000) in Hungarian.

In the context of Yemeni spoken Arabic, the PM 'Pamaanah' is widely used among Yemeni Arabic speakers in their daily communication. The word 'Pamaanah' literally means 'trust', 'faith', or 'honesty'. By virtue of its semantic value, the word 'Pamaanah' is pragmatically used as an expression of oath in the Yemeni culture. A speaker can use it at the beginning or the end of the propositional content or force of his utterance to express his commitment of telling the truth or performing the illocutionary act intended in the utterance. The function of the PM 'Pamaanah', however, is not confined to such contexts. In fact, it is found that this marker has multiple pragmatic functions that serve as clues to the ideational and interpersonal language spoken by Yemeni speakers in different situational and social contexts. The multifunctionality of the pragmatic marker 'Pamaanah' in several contexts of the Yemeni variety of spoken Arabic draws the interest of the researcher for conducting this study.

\subsection{Aims of the Study}

With the aforementioned rationale in its background, the present study aims at exploring and describing the multiple functions of the PM 'Pamaanah' in the corpus of Yemeni spoken Arabic.

\section{Literature Review}

\subsection{Pragmatic Markers: Definitions and Functions}

The definition of the term PMs is unclear and there is little consensus on using a specific term to refer to those linguistic elements/markers that appear along with the ideational and interpersonal utterances in a spoken discourse (Aijmer and Vandenbergen, 2011, p. 224). However, on account of the various functions and characteristics of the markers, some terms were used in the literature. According to Aijmer and Vandenbergen, (2011, p. 226), the best of these terms are pragmatic markers (used e.g. by Brinton, 1996), discourse markers (used e.g. by Schiffrin, 1987 and Jucker and Ziv, 1998), discourse particle (Hansen 1998; Aijmer 2002), and pragmatic particle (Östman, 1995).

The two terms, 'pragmatics markers' and 'discourse markers' (henceforth DMs), are the most frequently used labels by researchers concerned with their distinctive functions in spoken and written discourse. Comparing the two terms with reference to their functionality, PMs have many interactional functions that are mainly related to spoken discourse; whereas DMs have fewer functions, which are basically related to written discourse (Azi, 2018, p. 51). According to Aijmer and Vandenbergen (2011, p. 227), PM is most commonly used as an umbrella term covering forms with a wide variety of functions both on the interpersonal and textual levels. The researchers maintain that PM is preferred to DM when the markers have a pragmatic rather than discoursemarking function. This refers to the situation when the markers serve to mark illocutionary 
force or have an interactional function. As for the distinction between the terms 'marker' and particle, the term 'marker' captures the fact that an element functions as a signal instructing the hearer how the message should be interpreted; whereas the term 'particle' suggests a formal restriction of a wellestablished grammatical label for a part of speech (Anderson and Fretheim, 2000, p. 1).

In view of the literature concerning the definition and functions of PMs, Furko (2017, p. 2) defines PMs "as set of syntactically diverse linguistic items (for example, 'of course', 'surely', 'I think', 'well' and 'so on') that are used for a variety of attitudinal and meta-communicative functions, lack conceptual meaning, and whose distinctive properties include indexicality, contextdependence and multifunctionality." The researcher suggests that PMs comprise a functional class of linguistic items that do not typically change the propositional meaning of an utterance but are essential for the organization and structuring of discourse, for marking the speaker's attitudes to the proposition being expressed as well as for facilitating processes of pragmatic inferences.

In his title "Pragmatic markers revisited with a focus on 'you know' in adult and adolescent talk', Erman (2001, p. 1339) maintains that PMs "have little or no meaning in themselves and can only be understood either through clues in the context and/or situation, or else by having a conventionalized pragmatic meaning mapped onto them." Revisiting PMs with focus on 'you know' marker, Erman (2001) proposes three main functional domains in which markers are used as monitors in communication, namely the textual, social and metalinguistic domains. According to him, PMs functioning as textual monitors are used by a speaker to turn fragmented pieces of discourse into a coherent in a text. As for those PMs functioning as social monitors, they are used for negotiating the meaning and management of discourse and ensuring that the channel is open between interlocutors. PMs functioning as metalinguistic monitors are used as comments, not on the propositional content of the message, but on the implications of it and on the speaker's intended effect with it (p. 1339).

Based on spoken conversational data, Brinton (1996) listed a number of combining formal and functional features for PMs. They are as follows:

1. Phonological and lexical features: a) they are short and phonologically reduced; b) they form a short tone group; c) they are marginal forms and hence difficult to place within traditional word class.

2. Syntactic features: a) they are restricted to the sentence-initial position; b) they occur outside the syntactic structure or are only loosely attached to it; c) they are optional.

3. Semantic features: a) they have little or no propositional meaning.

4. Functional features: a) they are multifunctional, operating on several linguistic levels simultaneously.

5. Sociolinguistic and stylistic features: a) they are a feature of oral rather than written discourse and are associated with informality; b) they appear with high frequency; c) they are stylistically stigmatized; d) they are gender specific and more typical of women's speech (Aijmer and Vandenbergen, (2011, pp. 225-226).

Aijmer et al. (2006) introduced another feature characterizing PMs. This feature is referred to as markers' reflexivity. In fact, such markers comment on the utterance and assist in the interpretation of that utterance. The marker in this sense has a meta status and understanding of its functioning entails defining its metalinguistic/micropragmatic role. Aijmer et al. (2006) argue that PMs have the interactional and argumentative function in the discourse to signal the speaker's position vis- a 
vis the hearer's, his/her expectations or contextual assumptions.

In his discussion about the information encoded by linguistic expression in a sentence, Fraser (1996) divided sentence meaning into two parts: the propositional content of sentence which represents a state of the world that the speaker wants to convey to the addressee; and the non-propositional part of sentence meaning which corresponds to the different types of potential direct messages a sentence may convey. The non-propositional part of sentence meaning is analyzed into different types of signals which are called PMs. Fraser (1996, p. 167) states that "these PMs, taken to be separate and distinct from the propositional content of the sentence, are the linguistically encoded clues which signal the speaker's potential communicative intentions." In this regard, Fraser (1996, p. 168) classified messages, and their associated PMs, into four types: a) a basic marker signals the force of the basic message; b) a commentary marker signals a message which comments on the basic message; c) a parallel marker signals a message in addition to the basic message; and a discourse marker signals the relationship of the basic message to the foregoing discourse. In alignment with definitions of PMs focusing on their sociolinguistic, interactional, and extra-linguistic facets rather than on their logical connective qualities, Beeching (2016, p. 5) adopts the term PMs rather than DMs to highlight their interpersonal meaning. She maintains that PMs are "a fundamental part of oral fluency and respond to the spontaneous, interactional, social, sociable and polite properties of conversation" (p. 4). For the purpose of the present study, the term PM will be used to explore the pragmatic multiple functions of the linguistic expression 'Pamaanah' in Yemeni spoken Arabic.

\subsection{Theoretical Frameworks to the Study of PMs}

In view of the fact that PMs have a wide range of functions in different interactional contexts of spoken discourse, a number of theoretical frameworks have been considered in describing and constraining the multifunctionality of PMs. For the purpose of the present study, the researcher will draw on the most relevant frameworks accounting for the functions of PMs in spoken discourse. According to Aijmer and Vandenbergen, (2011, p. 229), PMs can be fitted in the speech act theory. Brown and Levinson (1987) considered PMs as markers of illocutionary force (Illocutionary Force Indicating Devices [IFIDs]). Searle (1976) categorized illocutionary speech force into five types: representatives, directives, commissives, expressives, and declaratives. The function of PMs is not restricted to the situation described above. In fact, PMs can encompass certain underlying social and cultural functions. Östman (1995) suggests that PMs can have functions related to social and cultural parameters such as politeness, discourse coherence, or involvement. In this regard, Brown and Levinson's (1987) politeness theory is found relevant in accounting for the functions of PMs used by speakers in their social and cultural interaction. The politeness framework is founded on the notion of 'face'. Brown and Levinson (1987) outline three strategies for mitigating the face threat it causes: negative politeness, which acknowledges and downplays the magnitude of the imposition to show respect for the addressee's negative face ('if it's not too much trouble, could you...'); positive politeness, which builds up the addressee's positive face (a request prefaced with a compliment); and indirectness, which can give the speaker plausible deniability in case the addressee objects to the request ('it's chilly in here' as a request that someone close a window).

Halliday's (1994) model, 'Functional Systemic Linguistics' (FSL), provides an efficacious 
framework that accounts for the functions of PMs. The model is described in terms of threefold metafunctions: experiential, textual, and interpersonal. According to Halliday's model, MPs are categorized as textual or interpersonal. Brinton (2008) has distinguished between textual and interpersonal in grouping the functions of PMs into two classes. Those PMs which relate to the structuring of discourse as text are classed as textual; whereas those which relate to the expression of speaker's attitudes are classed as interpersonal. PMs functioning as textual are used for initiating and ending discourse, marking boundaries in the discourse, signaling topic shift and repairing discourse. PMs functioning as interpersonal are used for expressing responses and attitudes as well as solidarity and face-saving.

Sperber and Wilson's (1986) theory of relevance sets a useful framework for analyzing PMs. According to this theory, PMs are viewed as signals guiding the hearer's interpretation of an utterance. Indeed, such PMs are used to reduce the burden on the part of hearer in arriving at the intended meaning of the speaker. Among the studies that used relevance theory as a framework for analyzing PMs are Blakemore (1987), Watts (1988), Ifantidou (2000), Anderson (2001), and Bidaoui (2015).

\subsection{Previous Related Studies}

A large number of studies have been conducted to investigate those linguistic elements/markers that appear along with the ideational and interpersonal utterances in a spoken discourse. Most of these studies adopted the two terms DMs and PMs in accounting for the functions of such linguistic markers. For convenience of reference, the two terms will be used interchangeably throughout this section. In the context of English, some PMs/DMs such as: 'well', 'like', 'you know', 'sort of' 'of course', 'I mean', and 'so', have been extensively studied within standard
English and across regional and social varieties of English (Schourup, 1985; Schiffrin, 1987; De Klerk, 2005, Anderson, 2001; Janet Holmes, 1986, amongst others). For instance, the PM 'well' has been examined by a considerable number of researchers like, Schourup, 1985; Schiffrin, 1987; Watts, 1989; Jucker, 1993; de Klerk, 2005; García Vizcíano and Martínez-Cabeza, 2005; Cuenca, 2008; just to mention a few. All the researchers have considered 'well' as a PM with a highly complex functional scope. Aijmer and SimonVandenbergen (2003) consider it as "a recalcitrant marker (...) which varies its function depending on the situation."

With regard to the context of spoken varieties of Arabic, a number of related studies have been conducted on the functions of some PMs and DMs used in the spoken discourse of Arabic dialects across Arabic countries (cf., Gaddafi, 1990; Ahmed, 2014 [Libyan Arabic]; Al-Batal,1994 [Lebanese Arabic]; Bidaoui, 2015 [Algerian Arabic, Moroccan Arabic, and Egyptian Arabic]; Mughazy, 2003, Ismail, 2015; Hussein, 2016 [Egyptian Arabic]; Farghal, 1995; Kanakri and Al-Harahsheh, 2013; Mehawesh and Jaradat, 2015; AlKhawaldeh 2018 [Jordanian Arabic]; Al Rousan, 2015; Alshamari, 2015 [Saudi Arabic]; Alazzawie, 2015 [Iraqi Arabic]. For limitation of the research paper, some related studies based on spoken corpus of Arabic dialects will be reviewed. To begin with, AlBatal (1994) has conducted a study aimed at exploring the uses and functions of certain PMs in Lebanese Arabic (LA) and Modern Standard Arabic (MSA). As the present study is confined to PMs used in spoken varieties of Arabic, we will focus on those PMs in Lebanese spoken Arabic. The targeted LA PMs were 'ya?ni' (I mean), 'bass' (but), 'halla' (now), 'tayyeb' (well), and 'ba'a' (so and therefore). The researcher collected his data from spoken TV and radio programs and recorded interviews. Based on the relevance- 
analysis framework, the study findings showed that the LA PMs function at both levels: 'sentence and discourse'. Similar to the English PM 'I mean', the LA PM ' $y a$ ?ni' (I mean) is used as a filler in spoken discourse. The LA PM 'bass' (but) is used to indicate an adversative relationship between text chunks; the PM 'halla' (now) is used to imply a shift in the movement of discourse and to change a discourse topic. Like 'so' and 'therefore' in English, ' $b a$ ' $a$ ' (so and therefore) is used to point to a conclusive relationship between two elements of discourse. The PM 'tayyeb' (well) implies a shift between speakers in discourse.

In her study about the uses of the DM 'bahi' (okay) in daily Libyan Arabic (LA) conversations, Ahmed (2014) collected data from twenty-two sets of videos recording ten male and female subjects, and six audiorecorded conversations produced by LA speakers. Addressing her aim of examining the uses of the targeted DM on the basis of gender differences, the researcher analyzed some of the audio-recorded conversations in terms of frequency and use. The findings of the study revealed that 'bahi' functions as a DM carrying distinctive meanings in different contexts such as: agreement, warning, expectation of more, showing admiration, blaming, and ending arguments, among others. The results analysis of the recorded conversations part indicated that the tendency in using the DM by male and female speakers was almost the same in terms of the intended meanings, but higher of frequency among the female ones.

In the context of Egyptian Arabic (EA), two interesting related studies were done by Mughazy (2003) and Ismail (2015). Mughazy (2003) studied the functions of the PM 'wallahi' in EA with reference to Brown and Levenson's (1987) theory of politeness. The researcher believed that the PM 'wallahi' (by the God) along with the markers, 'winnabi' (by the Prophet), and 'wilinjieel' (by the
Bible), are used interchangeably as expressions of oath. According to the researcher, the use of such oath expressions is motivated by the religious beliefs of the speaker. The researcher also found that nonoath 'wallahi' is used as a discourse particle in EA to serve two functions. The first one is to function as a politeness marker, preceding potentially face-threating speech acts (e.g. advising, suggesting, and criticizing) and mitigating and reducing undesired effects (e.g. impositions) in spoken conversations. The other one is used as a power marker to determine the (most appropriate) politeness strategies to be employed in a given context.

In his analysis of the three PMs: ' $b a$ ' $a$ ', 'ayyeb', and 'tab' (they literary mean 'ok'), Ismail (2015) analyzed seven Egyptian movies in order to bring out their functions in EA context. The findings of the analysis revealed that ' $b a$ ' $a$ ' performs the functions of: 'coherence, contrast, end of encounter, conclusion, interpersonal management, end of patience, surprise, sarcasm or politeness. The study analysis also showed that the PMs 'tayyeb' and 'tab' share the same functions though being different in spelling. They are commonly used as response tokens with similar functions related to acknowledgment, giving consent, mitigating, a directive speech act and threatening.

With regard to the Jordanian context of Arabic varieties, Farghal (1995) investigated the pragmatics of 'inshallah' in JA. The researcher believed that this expression has shifted extensively from its semantic import by acquiring a range of spectrum of illocutions. The findings of the study showed that the DM 'inshallah' demonstrates diverse illocutions (speech act functions) in speech situation, for instance, directive, commissive, and expressive.

Based on the frameworks of discourse analytical approach and translation theory of their analyses, Kanakri and Al-Harahsheh 
(2013) examined the functions of the dialectal PM of Arabic '?a:di' (ok). The researchers collected their data from 20 video-taped dyadic Jordanian Arabic conversations. The results of the study showed that the Arabic PM '?a:di' was used to perform the following pragmatic functions: supporting or extenuating a difficult situation; asking for a permission to do something; communicating disapproval or rebuke; showing discontent of certain incidents; expressing the meaning of contempt, disdain, or scorn; expressing courtesy; showing an acceptance of but without bearing any responsibility taking an action; saving one's face; and expressing an indirect interrogation or criticism of a certain behavior. Along the same line, Alazzawie (2015) investigated the uses and distribution of the marker ' $C a: d i$ ' (ok) in Iraqi spoken Arabic. The findings of the study indicated that this PM has both pragmatic functions as well as discoursal functions. The pragmatic functions are manifested in indicating the speaker's beliefs, attitudes, and opinions; whereas those discoursal functions are realized in terms of signaling and maintaining textual cohesion and organization as well as the flow of conversation. The findings also showed that this marker has multiple uses and functions in different situations such as: indicating sympathy, support, encouragement, consolation, mitigation, agreement, disagreement, reprimand, sarcasm, and permission.

A recent study has been carried out by $\mathrm{Al}$ Rousan (2015) on the pragmatic functions of the PM 'maS nafsak' (be with yourself) in the context of Saudi Arabic (SA). Out of 262 WhatsApp and BBM messages collected from 17 undergraduate male students aged 18-19 at Yanbu University, a total of 132 cases of the PM 'maS nafsak' were analyzed qualitatively. Based on the analysis of contextualized conversations, 12 pragmatic functions were identified. These functions are realized in terms of refusal, lack of interest/indifference, annoyance, reprimanding, doubt, unwillingness, distancing one' self from others, challenging, scolding, disappointment, choice, and preserving personal privacy. The findings of the study also showed that the PM ' $m a$ S nafsak' was observed to have meanings that were coded in the consequent utterances, and it can also have meanings when it occurs on its own.

In connection with the findings of the above reviewed studies, the contribution of the present study emerges from its attempt to add further insights to the existing literature on how certain linguistic elements/markers, considered in their contextual distributions across languages and regional varieties, convey messages and perform functions in social interaction. The novelty of this study lies in its purpose of examining the functions of a new PM that is used in contexts other than the ones reviewed before. In fact, it aims at exploring and describing the multiple functions of the PM 'Pamaanah' in the spoken variety of Yemeni Arabic (YA). An eclectic analytical method is adopted for the purpose of the study. This method draws on ideas derived from the theoretical frameworks of the speech act theory, politeness theory, model of functional systemic linguistics (the interpersonal metafunction), and relevance theory.

\section{Methodology}

\subsection{Corpus of the Study and Procedure}

The present study is descriptive in nature. It attempts to investigate and describe the multiple functions of the PM 'Pamaanah' in the context of YA. In view of the assumption that the targeted PM is commonly used in the spoken discourse of YA, a corpus of Yemeni spoken Arabic was collected as the source data of the analysis. Aijmer and Vandenbergen (2011, p. 231) believe that "[i]n studies of PMs the emphasis is on (preferably spoken) corpus of data." Twenty male and female students of 
English at Sana'a University were given a task of recording genuine interactional conversations among YA speakers. They were briefed about the main purpose of their task and asked not to disclose it to the targeted subjects. They were also informed to target subjects that vary in gender, status, and role and topics that cover everyday situations. After a month of data collection, the students submitted the recorded data to their concerned instructor who compressed them in a zip file and sent it to the researcher for analysis. A total of 187 recorded conversations were analyzed carefully. Out of the 187, 13 recorded conversations were discarded as they do not contain occurrences of the targeted marker. 174 occurrences of the PMs 'Pamaanah' were analyzed further and categorized in terms of functions.

\section{Results and Discussion}

The present study aims to investigate the multifunctionality of the PM 'Pamaanah' in Yemeni spoken Arabic. Context-bounded analysis of the 174 occurrences of the PM 'Pamaanah' used among Yemeni native speakers of Arabic shows that this marker performs multiple functions in their interactional communication. These functions are categorized and discussed in more detail with some illustrative extracts from the compiled data in the following.

\subsection{To Function as an Expression of Oath}

According to the analysis of the spoken corpus of the study, it has been observed that the PM '?amaanah' was highly used as an expression of oath. In fact, the use of such an oath expression is motivated by the semantic value of the word 'Pamaanah' which literally means 'trust', 'faith', or 'honesty'. It can be used at the beginning or the end of the propositional content or force of speaker's utterance to express his commitment of telling the truth or performing the illocutionary act intended in the utterance. The following extract illustrates this point.

\section{Extract 1}

Sarah: Ruqaih, teshti shee men Taiz? Ana

Mesaferah bokrah.

[Ruqaih, do you need anything from

Taiz? I'm travelling tomorrow]

Ruqaih: Ehlefi! Ma asadeqek. [Swear! I can't believe you!]

Sarah: Pamaanah ma akdheb alyash.

[?amaanah I don't lie to you.]

The above extract shows that the PM 'Pamaanah' is used at the beginning of Sarah's utterance: 'Pamaanah ma akdheb alyash. (Pamaanah I don't lie to you.). In this context, this marker functions as an expression of oath expressing Sarah's commitment to the truth of the propositional content of her utterance that is 'she is not lying to her about travelling to Taiz'. As a matter of fact, 'Pamaanah' is one of the alternative oath expressions used in Yemeni culture. Expressions like 'wallah' (by Allah), 'walmuss-haf' (by the Qura'an), and 'washarafi' (on my honor) are interchangeably used as forms of oath among Yemeni native speakers of Arabic. It is by virtue of the religious, social, or semantic value of the words, such oath expressions are used to express the speaker's commitment to what he says or performs (cf., Mughazy, 2003 and AlKhawaldeh, 2018 ['wallahi' in EA and JA]).

Another example accounting for the use of the PM 'Pamaanah' as an expression of oath is taken from shopping conversations. Consider the extract below:

\section{Extract 2:}

The customer: Hal hadha ala'sal assli? [Is this honey genuine?]

Storekeeper: Assli Pamaanah. [Genuine Pamaanah]

The situation of the above extract is in a honey store where the customer is trying to buy honey. The exchanges of the conversation indicate that the customer asked the storekeeper whether the quality of the honey is genuine. Expressing his commitment of selling good quality, the storekeeper used the PM 
'Pamaanah' as an oath at the end of his utterance. In fact, the oath expression, 'Pamaanah', is frequently used among Yemeni speakers of Arabic in their business transactions, especially among sellers.

\subsection{To Function as a Commitment Marker to a Future Action on the Part of the Speaker and the Addressee}

Austin (1975), in his speech act theory, refers to speech acts of commitment as those "committing [one] to certain future conduct" (P. 89). This term has been used in connection with the commissives type of illocutionary acts classified by Searle (1979). Speech acts involve different types of speakers' commitment. For example, a promise engages a speaker to do something pleasant, a threat involves the speaker to do something unpleasant, and a request implies the speaker's attempt to get the hearer to accomplish the action requested for. Searle, (1979) referred to different devices that are used to indicate how an illocutionary force of an utterance is interpreted. According to him, these devices aid the hearer in identifying the illocutionary force of the utterance. They are referred to as the illocutionary force indicating devices (IFIDs). In this regard, Brown and Levinson (1987) considered PMs as markers of IFIDs. The following extracts, found in the corpus of the study, illustrate how the PM 'Pamaanah' functions as a commitment marker on the part of the speaker.

\section{Extract 3:}

Sam: Ma tejeebli idha hazmtuh fi alnahayi?

[What will you give me if I defeat him in the final?]

His brother: Amahan ashtari lak ahla jawal.

[?amaanah I buy you a nice mobile.]

Sam: Khleek a'nd wadak. [keep your promise] His brother: Tamam! [Done!]

\section{Extract 4:}

Father: (Addressing his son) ya ebni dhaker! ashti darajat halyah. [son, study! I want good grade.]
Son: Hya ya abah! Hai gher darajat denya! [common dad! It is just grade of lifeworld] Father: Bain aqulak dhaker! Pamaanah lu tersab la adhrubak. [I'm saying study! Pamaanah if you fail the exam, I'll beat you.] In the above extracts (3 and 4), the PM 'Pamaanah' is used at the beginning of the speakers' utterances. In both of the utterances, the speakers commit themselves to the performance of future act on conditional actions being fulfilled or broken by the addressees. In extract 3, Sam's brother commits himself to buying Sam a mobile in case he defeats his counterpart in the finals of tennis tournament. However, the context of extract 4 is different; here the father commits himself of punishing his son if he fails in the exam. Working within the relevancetheoretical framework, it is found that the PM 'Pamaanah', in both extracts, works as a signal guiding the addressees to infer the functions of the perspective utterances. In extract 3, Sam inferred his brother's utterance as a promise; and that is manifested in his reply: 'keep your promise'. In extract 4, the father's utterance implies a threat; and that is figured out from the context. Searle, (1979) classified promises and threats as commissive acts. A promising commissive act is intended to be beneficial for the receiver and/or is at least believed to be so by the promiser, the receiver, or both; whereas a threatening commissive act is intended to be detrimental to the receiver and/or is at least believed to be so by the threatener, the receiver, or both.

Unlike the contextual distributions of the commissive acts discussed above, the PM 'Pamaanah' can also function as a commitment marker to a future action to be accomplished by the addressee. Consider the following illustrative extract:

\section{Extract 5}

Ahmed: Sami, ana mesafer assaudyah omerah. [Sami, I'm travelling to Saudi Arabia for umrah.] 
Sami: Mata mesafer?! [When are you travelling?!]

Ahmed: Allailah ba'd Al-Isha. [Tonight, after alisha prayer]

Sami: Pamaanah ed'aili a'nd al-kabah.

[?amaanah, pray for me at al Kabah]

Ahmed: Insha' allah. [God's willing]

The context of extract 5 demonstrates that the speaker (Sami) commits the addressee (Ahmed) to his request of praying for him at alkabah when he comes to know that he is travelling to Saudi Arabia for Umrah. Likewise, the PM 'Pamaanah', in the above extract, is considered as a clue getting the addressee infer the function of the utterance. Relying on the relevance of the speaker's utterance in the context, Ahmed inferred Sami's utterance as commitment getting him to accomplish the action requested for; and that is realized in his preferred response 'insha' allah'.

\subsection{To Function as a Mitigation Marker, Preceding Potentially Face-Threating Speech Acts}

Mitigation is a term introduced by Fraser (1980) in pragmatics; and it refers to those linguistic devices used by speakers to protect themselves against various interactional risks. The use of mitigation marker in interactional discourse is one of the strategies based on the positive/negative politeness theory proposed by Brown and Levinson (1987). The function of such strategies is to attenuate the facethreatening impact of directive illocutionary acts such as requesting, and advising. The use of the PM 'Pamaanah' in Yemeni spoken Arabic is found as one of the politeness strategies used to introduce the directive acts and soften their impact on the addressees. The following extract exemplifies one of the directives acts (i.e. requesting).

\section{Extract 5:}

Amjed: Pamaanah emsak alketab atwadha. [?amaanah hold the book while I have my ablution]
Saleh: tayeb? [ok]

Based on the context of the conversation above, Amjed requests Saleh to hold the book while he takes his ablution. To avoid sense of imposition and face-threatening on the part of the addressee, Amjed used the PM '?amaanah' as a politeness marker to alleviate the impact of his request and make it less direct and more appropriate. Like the DM 'wallahi' in JA (Al-Khawaldeh, 2018), the PM 'Pamaanah' functions as a mitigating marker softening the speaker's propositional content and avoiding potential embarrassment on the part of the addressee.

\subsection{To Function as a Signal Introducing Reprimanding}

A reprimand is considered as a communicative illocutionary act of the assertive type and is defined as "an accusation with the special mode of achievement of adding personal displeasure as punishment for the wrong doing" (Vanderveken, 1990, p. 179). The utterance of reprimand is often perceived as a face-threatening act for the addressee is presumed to be offended by the propositional force of the utterance. To maintain harmony and friendliness in social interaction, a speaker usually tends to use solidarity over deference politeness strategies when he expresses his disapproval of someone's wrong doing. One of the positive politeness strategies assuring solidarity among interlocutors is reflected in the speaker's use of certain signals to introduce his reprimanding. The use of the PM 'Pamaanah' to introduce reprimand in social interaction is found as one of the politeness strategies used in Yemeni spoken Arabic. In fact, this marker is found to minimize the facethreatening act underlying the propositional content of the speaker's utterance. The following extract illustrates this point.

\section{Extract 6:}

Salwa: (Greeting her mother-in-law) Salam alikum. [Salam Alikum] 
Mother-in-law: Wa'alesh alsalam. Pamaanah wala etesal tes ali alina! [Walikum alsalam. Pamaanah no call to ask about us!]

Salwa: Ma afal ya amah! Mabesh shabakeh. [What can I do Mom?! There is no coverage.] It is noticed in the extract above that the PM 'Pamaanah' is used to introduce the reprimand of Salwa's mother-in-law. She reprimands Salwa for not calling her. In her turn, Salwa justified her assumed fault for not having coverage to make calls.

\subsection{To Function as an Attitude Marker Expressing a Speaker's Attitude and Emotion}

Interacting with the propositional content of speaker's utterance, an interlocutor usually uses certain PMs to express his feelings and emotion towards the underlying propositional meaning of the utterance. Such PMs are categorized as attitude markers. They are defined as a set of expressions, which "serve as a means by which the user of the language makes obvious what his feelings, emotions or views are about the propositional content of the utterance being made" (De Bruyn, 1998, p. 127). The contextual analysis of the corpus of the study shows that the PM 'Pamaanah' is found to function as an attitude marker in the spoken discourse of YA. The following extracts are illustrative examples demonstrating how the addressees express their attitudes towards the propositional content/force of the speaker's utterance.

\section{Extract 7}

Amani: Tarafi Umrana alladhi mat zawjaha qabel khamsah shahoor? [Do you know Umrana whose husband died five months ago?] Sali: Aywah ma laha? [Yes, what happened to her?!]

Amani: Alyaum eras-ha. [Today is her wedding]

Sali: Pamaanah!

\section{Extract 8}

Amal: (Addressing her younger sister) lan takhruji aw tedi khadwah men albeit ela ba'd ma tasta'dheni meni awalan. [you will never get out or move a step out of the house unless you take permission from me first.]

Younger sister: Pamaanah!! Aw anti abi asta'dhen menek! [?amaanah!! Are you my father from whom I take permission!] In extract 7, Sali's utterance (Pamaanah!) does not contain propositional information; however, it achieves an interactional effect which suggests that speaker and hearer share parts of their contextual background. Considering the intonation features of the marker Pamaanah (i.e., falling-rising tone), it is found that it has the pragmatic effect of marking Sali's surprise about the early marriage of Um-rana whose husband has recently died. Similarly, the utterance (Pamaanah) of Amal's younger sister, in extract 8 , does not convey any message to the speaker; nevertheless, it addresses the propositional force of Amal's utterance which implies face-threating act. In fact, Amal's utterance functions as a directive illocutionary act seeking effect on the behavior of her younger sister (taking permission from her before leaving the house). The rising-falling tone features of the uttered marker 'Pamaanah' account for the attitude of the younger sister towards Amal's face-threating act. To make it clear, it functions as a sarcastic marker expressing her critical attitude towards her sister's directive act. In consideration of Halliday's (1994) model, 'Functional Systemic Linguistics' (FSL), it is found that the PM 'Pamaanah' in YA is like the English marker 'really!'; it has an interpersonal function expressing the speaker's attitude towards the underlying propositional content or force of the interlocutor's utterance.

Another context accounting for the function of the PM 'Pamaanah' as an attitude marker is found in the speaker's expression of his emotional state towards an emotion-evoking situation. The extract below is an example of this context. 


\section{Extract 9}

Mujahed: Maher, Mansour zameelana hasaluh hadeth! [Maher, our classmate, Mansour, had an accident]

Maher: Mata? Eysh waqa buh? [When? What happened to him?]

Mujahed: Ams allail. Hasaluh hadeth wa anqata'at saquh alyumna. [Yesterday night. $\mathrm{He}$ had an accident and had his right leg cut off.] Maher: Pamaanah!!

As observed in extract 9, the propositional content of Mujahed's utterance contains emotion-evoking news about one of his classmates who had an accident and got his right leg cut off. Interacting with such news, Maher uses the PM 'Pamaanah' in a levelpitch tone to express his attitude towards the emotionally evoking event. In this regard, Sperber and Wilson's (1986) believe that an attitude marker is used to describe the attitude of a speaker towards a situation. This attitude includes the speaker's belief, feelings, and emotion.

\subsection{To Function as an Epistemic Marker Evaluating the Subjectivity of the Speaker's Propositional Content}

Epistemicity involves the speaker's or writer's evaluation, judgment and degree of commitment attached to the truth-value of a piece of information (De Hann, 1999 and González, 2005). Speakers use epistemic markers to establish, maintain and negotiate their epistemic claims in spoken discourse. PMs can illustrate an epistemic meaning when indicating a speaker's view on the reliability of an utterance or on a 'mode of knowing', e.g. indicating belief, deduction, sensory evidence (Aijmer and Simon-Vandenbergen 2003, p. 1127). Considering the spoken corpus of the present study, it is found that native speakers of YA use the PM 'Pamaanah' as epistemic marker expressing their subjective stance in their conservational interactions. The extract below serves as an example of the point.

\section{Extract 10}

Malak: Ma raiyk bal doctor Sa'ad? [What is your opinion about Dr. Sa'ad?]

Samyaha: ?amaanah, tayab jedan [?amaanah, he's very good.]

In the above conversation, Malak asks Samyaha's opinion about Dr. Sa'ad. In her turn, Samyaha expresses her personal view using the PM 'Pamaanah' as an epistemic marker indicating the subjectivity of her evaluation. Like the English epistemic marker 'in fact' (cf., Schwenter and Traugott 2000), the epistemic meaning implied in the PM Pamaanah illustrates the speaker's point of view with regard to the truth of the proposition.

\subsection{To Function as an Entreaty-Marker on Directive Act}

In a situation where a speaker's suggestion or request is declined, the speaker sometimes resorts to use certain markers to entreat the addressee on the targeted directive speech act. In fact, these markers add extra impact on the basic speech act of the utterance (Matsui, 2000 , p. 147). Based on a context-dependent analysis of the corpus of the study, it is found that PM 'Pamaanah' is used by native speakers of YA as an entreaty marker urging the addressee to fulfil the intended speech act. Consider the following example.

\section{Extract 11}

Majed: (Addressing his roommate) Khaleena neruh almahadherah jama'ah [Let's go to the lecture together]

Waheed: Ma qadert (I can't)

Majed: Pamaanah hya! (Pamaanah let's go!)

The extract above is an adjacency pair which involves two-part exchange. The first part contains a suggestion by Majed for Waheed to go together to the lecture. In the second part of the exchange, Waheed declines Majed's suggestion. In his turn, Majed repeats his request using the word 'Pamaanah' to serve as an entreaty marker persuading the addressee to perform the directive act intended in the utterance. 


\subsection{To Function as a Displeasure Marker on the Part of the Speaker}

A displeasure marker is used to signal the speaker's annoyance towards the addressee and/or the situation that gives rise to the state of his feeling. In his classification of pragmatic markers, Fraser (1996, p. 183) classified displeasure markers under the parallel pragmatic markers whose function is to signal an entire message in addition to the basic message. Considering the corpus of the Yemeni spoken Arabic, it is found that PM 'Pamaanah' is used to signal more or less specifically the force (the kind of message in contrast to its content) of the basic message. The extract below illustrates the point under discussion.

\section{Extract 12}

Daughter: (Addressing her mother) yamah ashti floos. [Mom, I want money.]

Mother: Ma besh alyoom ya benti! [No money today, daughter!]

Daughter: Yamah mashi! Qawa ashti floos dharoori. [Mom, No! Please I want money badly!]

Mother: Pamaanah men ayen ajeeb lesh wal wadha hakadha?! [?amaanah from where I

give you money and the situation is as such?!] The context of the above interaction demonstrates that the daughter requests money from her mother and the mother declines the request. The daughter later insists on her mother to give her money. Being annoyed by her daughter's insistence on her request and the situation of not being able to earn money to make ends meet, the mother expresses her displeasure towards her daughter's annoying insistence and the situation described above. This is manifested in the contextualized use of the MP 'Pamaanah' which signals exasperation on the part of the mother. As a matter of fact, the marker Pamaanah adds force to the mother's rhetorical question which implies a critical view addressing the daughter's annoying request. Like the English
PM 'for God's sake/in God's name', the Yemeni PM 'Pamaanah' is used to express the speaker's annoyance, impatience, and exasperation or to add force to the speaker's question/request.

\section{Conclusion}

The study explored and described the multiple functions of the PM 'Pamaanah' in the corpus of Yemeni spoken Arabic. Based on the analysis of the corpus of Yemenis' spoken discourse, it is found that the PM 'Pamaanah' has multiple functions that serve as clues to the ideational and interpersonal language spoken by Yemeni speakers in different situational and social contexts. The findings of the study showed that 'Pamaanah' functions as: an expression of oath; a commitment marker to future action on the part of the speaker and the addressee; a mitigation marker, preceding potentially face-threating speech acts; a signal introducing reprimanding; an attitude marker expressing a speaker's attitude and emotion; an epistemic marker evaluating the subjectivity of the speaker's propositional content; an entreaty-marker on directive act; and a displeasure marker on the part of the speaker. The multifunctionality of the marker 'Pamaanah' can extend its pragmatic contexts; in fact, there are some situational contexts where 'Pamaanah' functions as a discourse marker in conversational interactions. Such contexts are suggested to be investigated in further researches.

\section{Acknowledgments}

I would like to thank Dr. Ali Alhaidari, Sana'a University, for his assistance in collecting the data of the study.

\section{References}

Ahmed, K. (2014). The uses of 'bahi' as a discourse marker in daily Libyan Arabic conversations. International Journal of English Language \& Translation Studies, 2(1), 171-181. 
Aijmer, K. (2002). English discourse particles. Evidence from a corpus. Amsterdam, The Netherlands: John Benjamins.

Aijmer, K. \& A. M. Simon-Vandenbergen (2003). Well in English, Swedish and Dutch. Linguistics, 41 (6), 1123-1161.

Aijmer K, Vandenbergen A-M. (2011). Pragmatic markers. In Zienkowski J, Östman, \& J.Verschueren (eds.), Discursive pragmatics, 8, 223-247. Amsterdam, The Netherlands: John Benjamins.

Aijmer, K., A. Foolen \& A. M. SimonVandenbergen (2006). Pragmatic markers in translation: a methodological proposal. In Fischer (ed.): Approaches to discourse particles, 101-114.

Alazzawie, A. (2015). ' $Y a: d i$ ' as a discourse marker in spoken Iraqi Arabic. Theory and Practice in Language Studies, 5(7), 1352-1360.

Al-Batal, M. (1994). Connectives in Arabic diglossia: The case of Lebanese Arabic. In M. Eid, V. Cantarino, K. Walters (eds.), Perspectives on Arabic Linguistics, VI (pp. 91-119). Amsterdam: Benjamins. https://doi.org/10.1075/cilt.115.10alb.

Alkhalil, T. (2005). Discourse markers in Syrian Arabic: A study of halla, ya' $n$, tayyeb, and lakan. Unpublished Ph.D. thesis, University of Essex-UK.

Al-Khawaldeh, A. (2018). Uses of the discourse marker wallahi in Jordanian spoken Arabic: A pragma-discourse perspective. International Journal of Humanities and Social Science, 8(6), 114-123. doi:10.30845/ijhss.v8n6p.

Al Rousan, R. M. (2015). The use of discourse marker "maS nafsak" in Saudi Arabic: A pragmatic perspective. International Journal of Linguistics, 7(3), 33-48.

Alshamari, M. R. (2015). A relevancetheoretical account of three discourse markers in north Hail Arabic. Studies in Literature and Language, 11(1), 615.

Andersen, G. (2001). Pragmatic markers and sociolinguistic variation. Amsterdam, The Netherlands: John Benjamins.

Andersen, G. \& T. Fretheim (Eds). (2000). Pragmatic markers and propositional attitude. Amsterdam, The Netherlands: John Benjamins.

Azi, Y. (2018). Investigating Arabic pragmatic markers in spoken discourse: A literature review. International Journal of Linguistics, 10 (2), 48-72.

Beeching, Kate. (2016). Pragmatic markers in British English. Meaning in social interaction.

Cambridge: Cambridge University Press.

Bidaoui, A. (2015). Discourse markers of clarification and causality in Maghrebi and Egyptian dialects: a sociopragmatic perspective. Unpublished $\mathrm{Ph}$.D. thesis. University of Illinois at Urbana-Champaign.

Blakemore, D. (1987). Semantics constrains on relevance. Oxford: Blackwell.

Blakemore, D. (2002). Relevance and linguistic meaning: The semantics and pragmatics of discourse markers. Cambridge: Cambridge University Press.

Brinton, L. (1996). Pragmatic markers in English. Grammaticalization and discourse functions. Mouton de Gruyter.

Brinton, L. (2008). The comments clause in English. Syntactic origins and pragmatic development. Cambridge: Cambridge University Press.

Brown, G. and Yule, G. (1983). Discourse analysis. Cambridge: Cambridge University Press.

Brown, P., \& Levinson, S. (1987). Politeness: Some language universals in language 
use. Cambridge: Cambridge University Press.

Cuenca, M. -J. (2008). Pragmatic markers in contrast: The case of well. Journal of Pragmatics, 40 (8), 1373-1391.

De Bruyn, P. S. (1998). Pragmatic markers: The neglected part of speech. South African Journal of Linguistics, 16, (4), $127-135$. DOI: $\underline{10.1080 / 10118063.1998 .9724149}$

De Haan, F. (199). Evidentiality and epistemic modality: setting boundaries. Southwest Journal of Linguistics, 18 (1), 83101.

De Klerk, V. (2005). Procedural meanings of 'well' in a corpus of Xhosa English. Journal of Pragmatics, 37 (8), 11831205.

Gaddafi, A. M. (1990). Study of discourse markers in Libyan spoken Arabic. Unpublished Ph.D. thesis, Birkbeck: University of London.

García Vizcaino, M.J. \& M.A. MartinezCabeza. (2005). The pragmatics of well and Bueno in English and Spanish. International Pragmatics, 2 (1), 69-92.

González, M. (2005). An approach to Catalan evidentiality. Intercultural Pragmatics, 2 (4), 515-540.

Erman, B. (2001). Pragmatic markers revisited with a focus on 'you know' in adult and adolescent talk. Journal of Pragmatics, 33, 1337-1359.

Farghal, Mohammed. (1995). The pragmatics of 'inšāllah in Jordanian Arabic. Multilingua- Journal of Cross-Cultural and Interlanguage Communication, 14 (3), 253-270.

Fraser, B. (1980). Conversational mitigation. Journal of Pragmatics, (4), 341-350.

Fraser, B. (1996). Pragmatic markers. Pragmatics, 6 (2), 167-90.

Furko, P. (2017). Manipulative uses of pragmatic markers in political discourse. Palgrave Communications, (3), 1-8.

Halliday, M. (1994). An introduction to functional grammar, 2nd. ed. London: Edward Arnold.

Hansen, M. (1998). The function of discourse particles. A study with special reference to spoken standard French. Amsterdam, The Netherlands: John Benjamins.

Holmes, J. (1986). Functions of 'you know' in women's and men's speech. Language in Society, 15, 1-22.

Hussein, Mona. (2016). Propositional and non- propositional functions of /Keda/ in the language of Egyptian film. M.A thesis, The American University in Cairo.

Ifantidou, E. (2000). Procedural encoding of explicatures by the Modern Greek particle taha. In G. Andersen \& $\mathrm{T}$. Fretheim (Eds.), 119-143.

Ismail, A. (2015) tabasta'zenana ba'a: A corpus-based study of three discourse markers in Egyptian film language. Unpublished MA thesis. American University in Cairo.

Jucker, A. \& Y. Ziv (eds) (1998). Discourse markers. Description and theory. Amsterdam, the Netherlands: John Benjamins.

Kanakri, M. A., \& Al-Harahsheh, A. M. (2013). The discourse analysis and pragmatics of '?a: $d i$ ' in Jordanian spoken Arabic. International Journal of English Linguistics, 3 (6), 59.

Maschler, Y. (1998). Rotsè lishmoa kéta? 'Wanna hear something weird/funnt?' [lit.'a segment']: Segmenting Israeli Hebrew talk-in-interaction. In A. Jucker \& Y. Ziv (Eds.), 13-59.

Matsui, T. (2000). Linguistic encoding of the guarantee of relevance: Japanese sentence-final particle YO. In G. Anderson and T. Frethein (Eds.), 
Pragmatic Markers and Propositional Attitude (pp. 145-172),, Amsterdam: John Benjamins

Maynard, Senko. (1993). Discourse modality: Subjectivity, emotion, and voice in the Japanese language. Amsterdam and Philadelphia: John Benjamins.

Mehawesh, M and Jaradat, A. (2015). Inshallah: Extensive flouting of Grice's maxim of quality. Asian Social Science, 11(4), 319-327.

Mughazy, M. (2003). Discourse particles revisited: The case of wallahi in Egyptian Arabic. In Perspectives on Arabic Linguistics XV: Papers from the Fifteenth Annual Symposium on Arabic Linguistics, edited by Dilworth B. Parkinson and Samira Farwaneh, 318. Amsterdam, the Netherlands: John Benjamins.

Östman, J. (1981). You know. A discoursefunctional approach. Amsterdam, the Netherlands: John Benjamins.

Östman, J. (1995). Pragmatic particles twenty years after. Anglicana Turkuensia, 14, 95-108.

Schiffrin, D. (1987). Discourse markers. Cambridge: Cambridge University Press.

Schourup, L. (1999). Discourse markers: Tutorial overview. Lingua 107, 227265.
Schwenter, S. A. and E. C. Traugott (2000) Invoking scalarity. The development of in fact. Journal of Historical Pragmatics, 1(1), 7-25.

Searle, J. R. (1976). A classification of illocutionary acts. Language in Society, 5(1), 1-23.

Sperber, D. \& Wilson, D. (1986). Relevance: Communication and cognition (2nd edn. 1995). Oxford: Blackwell.

Tsai, P. S., \& Chu, W. H. (2017). The use of discourse markers among Mandarin Chinese Teachers, and Chinese as a second language and Chinese as a foreign language learners. Applied Linguistics, 38(5), 638-665.

Vanderveken, D. (1990). Meaning and speech acts. Volume I: Principles of language use; Volume II: Formal semantics of success and satisfaction. Cambridge: Cambridge University Press.

Vaskó, I. (2000). The interplay of Hungarian de (but) and is (too, either). In T. Fretheim, and G. Andersen (Eds.), Pragmatic markers and propositional attitude (pp. 255-263). Amsterdam, the Netherlands: John Benjamins.

Watts, R. (1988). A relevance-theory approach to commentary pragmatic markers: The case of actually, really, and basically. Acta linguistica Hungarica, 38 (1/4): 235-260). 


\title{
الوظائف المتعددة للعلامة التداولية "أمانة" في اللغة المنطوقة لليمنية الدارجة
}

\author{
د. حميد يحيى أحمد الزبيري \\ استاذ اللغويات التطبيقية المشارك

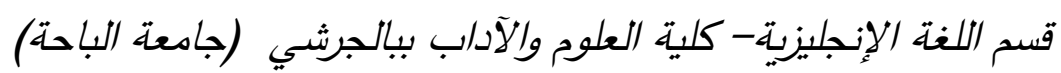

مستخلص. تهدف هذه الدراسة إلى استكشاف ووصف الوظائف المتعددة للعلامة التداولية "أمانة" في مدونة اللغة المنطوقة لليمنية الدارجة. تم تحليل ما مجموعه ؟ V بياناً مسجلاً صوتياً للمحادثات الطبيعية كمجموعة من اليمنية الدارجة. وتستند الدراسة إلى مقاربة تحليلية انتقائية اعتمدت على منطلق نظريات أفعال الكلام، والتهذيب، ونموذج اللغويات النظامية الوظيفية (فوق الوظيفية بين الأشخاص)، ونظرية الصلة. وتبين نتائج الدراسة أن العلامة التداولية "أمانة" تقوم بالأغراض التالية: تعبيرعن القسم؛ علامة إلزام لعمل مستقبلي على مستوى المتكلم والمُخَاطب؛ وعلامة تلطيف العبارة، تسبق أفعال الكلام الهجومية؛ وعلامة تأنيب؛ وعلامة دالة على موقف المتكلم ومشاعره؛ وعلامة السمات الإدراكية لتيّم ذاتية محتوى الفكرة للمتكلم؛ وعلامة التوسل على الأفعال التوجيهية؛ وعلامة استياء من جانب المتكلم. وأختتمت الدراسة باقتراح إجراء مزيدٍ من البحوث لاستكثاف ودراسة الوظائف الخطابية للعلامة. الكلمات المفتاحية: الوظائف المتعددة، علامات تدوالية، اللغة المنطوقة لليمنية الدارجة ، أمانة. 